\title{
Differentiating Ventricular Tachycardia and Supraventricular Tachycardia With Abberancy in Wide QRS complex Tachycardia
}

\author{
Andi Haryanto, Yoga Yuniadi
}

Department of Cardiology and Vascular Medicine, Faculty of Medicine, University of Indonesia and National Cardiovascular Center Harapan Kita, Jakarta.
Wide complex tachycardia is a quite common rhythm found in ECG. Basicly there are 3 arrhytmia that can cause wide QRS complex tachycardia, which are: Ventricle tachycardia (VT) which is the most common (80\%), Supraventricular tachycardia (SVT) with abberancy (15-20\%), and Atrioventriculare Reentrant Tacycardia (AVRT) with antidromic conduction ( I-6 \%). Correct diagnosis in differentiating SVT with aberancy and VT is important, due to the different patophysiology and different mechanism they present. Thus the therapy and management will be different, and miss treatment proven to be fatal.

Since ECG is still the main modality to provide the diagnosis in wide QRS complex tachycardia, many effort were done including the creation of algorhythms to help establish the diagnosis for wide complex tachycardia. The oldest and most widely used algorhythm is the Brugada algorhythm with respectable sensitivity and specificity. In 2007 Vereckei et al proposed a new algorhythm for differentiating VT and SVT with abberancy, and in 2008 Vereckei renew his previous algorhythm into only using single aVR lead to differentiate VT and SVT with abberancy, which was made solely based on the differences in the direction and velocity of the impulse. The latest method was again proposed by Brugada in 2010 which was called the ultrasimple Brugada criterion evethough there still haven't many research that discuss the accuracy of such criteria.

(J Kardiol Indones. 20 I3;34: 179-87)

Keywords: Algorhythm, Ventricular Tachycardia, Supraventricular with abberancy 
Jurnal

Kardiologi Indonesia

J Kardiol Indones. 2013;34:179-87

ISSN $0126 / 3773$

Tinjauan Pustaka

\title{
Membedakan Takikardia Ventrikel dan Takikardia Supraventrikular Dengan Aberansi Pada Takikardia Dengan Kompleks QRS Lebar
}

\author{
Andi Haryanto, Yoga Yuniadi
}

\begin{abstract}
Takikardia dengan kompleks QRS lebar adalah gambaran EKG yang cukup sering kita temukan. Pada dasarnya, ada 3 kelainan irama jantung yang dapat menghasilkan gambaran EKG takikardia dengan kompleks QRS lebar, yaitu: takikardia ventrikel (VT) merupakan yang paling umum ditemukan (80\%), takikardia supraventrikular (SVT) dengan aberansi (15-20\%), dan Atrioventriculare Reentrant Tacycardia (AVRT) dengan konduksi antidromik (1-6\%). Diagnosa yang tepat untuk membedakan SVT dengan aberansi dan VT sangatlah penting, karena keduanya memiliki patofisiologi dan mekanisme yang berbeda. Hal tersebut menyebabkan terapi yang perlu diberikanpun berbeda, dan kesalahan dari pemberian terapi dapat berakibat cukup fatal.

Karena EKG tetap merupakan modalitas utama untuk menegakkan diagnosis pada takikardia dengan kompleks QRS lebar, maka banyak algoritme yang diajukan untuk membantu menegakkan diagnosis. Algoritme yang paling umum digunakan adalah algoritme Brugada yang sudah sejak lama ada dan memiliki spesifisitas dan sensitifitas yang cukup baik. Pada tahun 2007 Vereckei et al. membuat algoritme baru yang digunakan untuk membedakan SVTdengan aberansi dan VT. Pada tahun 2008, Vereckei kembali memperbaharui algoritmenya dengan hanya menggunakan satu lead yaitu aVR saja untuk dapat membedakan VT dan SVT dengan aberansi dimana algoritme tersebut dibuat berdasarkan prinsip perbedaan arah vektor dan kecepatan impuls listrik. Selain itu ada pula metoda baru yang disebut sebagai ultrasimple Brugada criterion yang diajukan oleh Brugada pada tahun 2010 dimana belum banyak penelitian yang membahas mengenai akurasi dari kriteria tersebut.
\end{abstract}

(J Kardiol Indones. 2013;34:179-87)

Kata kunci : Algoritme, takikardia ventrikel, takikardia supraventrikel dengan aberansi

\section{Alamat Korespondensi:}

Dr. dr. Yoga Yuniadi, SpJP. Departemen Kardiologi dan Kedokteran Vaskular, Fakultas Kedokteran Universitas Indonesia dan Pusat Jantung Nasional Harapan Kita, Jakarta. Email: yogayl36@gmail.com
7 akikardia dengan kompleks QRS lebar adalah gambaran EKG yang cukup sering kita temukan. Secara definitif takikardia dengan kompleks QRS lebar adalah suatu irama dengan frekuensi QRS kompleks lebih dari 100/menit dan dengan durasi QRS kompleks > 120 ms. Sampai sekarang diagnosis dari takikardia dengan kompleks QRS lebar masih merupakan tantangan tersendiri dan masih sering didapatkan kesalahan diagnosis yang 
berujung pada penanganan yang salah yang bahkan dapat mengancam jiwa pasien. ${ }^{1}$

Pada dasarnya, ada 3 kelainan irama jantung yang dapat menghasilkan gambaran EKG takikardia dengan kompleks QRS lebar, yaitu: takikardia ventrikel (VT) merupakan yang paling umum ditemukan (80\%), takikardia supraventrikular (SVT) dengan aberansi (15 - 20 \%), dan Atrioventriculare Reentrant Tacycardia (AVRT) dengan konduksi antidromik (1 $-6 \%$ ). Untuk mendiagnosis ketiga kelainan tersebut diperlukan berbagai data, seperti anamnesa yang baik, pemeriksaan fisik, ataupun manuver-manuver tertentu, namun sampai saat ini modalitas yang paling sederhana dan cukup efektif untuk menegakkan diagnosa pada takikardia dengan kompleks QRS lebar adalah dengan menelaah gambaran EKG pasien dengan seksama. ${ }^{2}$

Diagnosa yang tepat untuk membedakan SVT dengan aberansi dan VT sangatlah penting, karena kedua kelainan tersebut sangatlah berbeda meskipun memiliki gambaran EKG yang mirip, SVT dengan aberansi dan VT memiliki patofisiologi dan mekanisme yang berbeda, dimana yang pertama

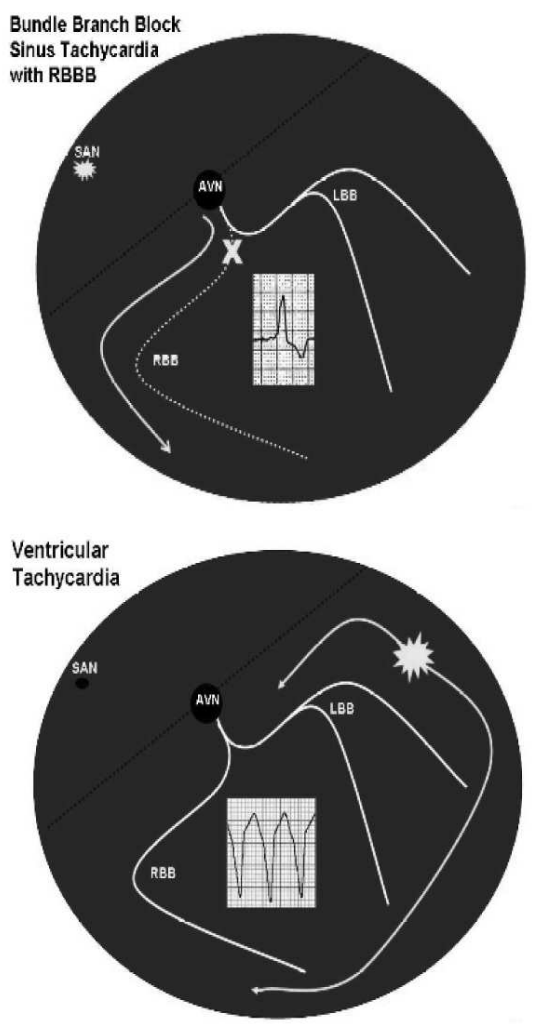

Gambar 1. Diagram yang menunjukkan perjalanan impuls elektrik pada VT (kiri) dan SVT dengan aberansi (kanan). ${ }^{3}$ bersumber dari supraventrikel, sedangkan yang kedua berasal dari ventrikel. Hal tersebut menyebabkan terapi yang perlu diberikanpun berbeda, dan kesalahan dari pemberian terapi dapat berakibat cukup fatal. ${ }^{2}$

Karena EKG tetap merupakan modalitas utama untuk menegakkan diagnosis pada takikardia dengan kompleks QRS lebar, maka banyak algoritme yang diajukan untuk membantu menegakkan diagnosis. Algoritme-algoritme tersebut digunakan untuk membantu kita untuk membedakan VT dan SVT dengan aberansi, namun sampai sekarang belum ada konsensus jelas mengenai algoritme mana yang memiliki sensitivitas dan spesifisitas yang terbaik. ${ }^{2}$

\section{Algoritme Brugada}

Pada tahun 1991, Brugada et al. mengadakan penelitian dengan mengevaluasi karakteristik-karakteristik EKG yang sudah ada untuk menentukan karakteristik mana yang memiliki akurasi yang terbaik. Brugada et al. mengumpulkan karakteristik-karakteristik EKG yang sudah ada sebelumnya yaitu: disosiasi atrioventrikular, deviasi aksis ke kiri, kompleks QRS > 140 ms, serta kriteria-kriteria morfologi pada sandapan prekordial yang diajukan oleh Wellens et al lalu melakukan uji diagnostik untuk menentukan akurasi dari karakteristik tersebut. ${ }^{1,4}$

Selain kriteria-kriteria lama tersebut, Brugada et al. juga menemukan karakteristik baru dari penelitiannya. Brugada et al menemukan semua SVT dengan aberansi setidaknya memiliki satu sandapan prekordial dengan kompleks RS, namun hanya 45\% dari VT yang sama sekali tidak memiliki kompleks RS di sandapan prekordialnya. Sehingga kriteria ini memiliki spesifisitas $100 \%$. Brugada et al juga mengukur interval RS dari semua rekaman EKG yang memiliki kompleks RS dan mendapatkan tidak ada SVT dengan aberansi yang memiliki interval RS > $100 \mathrm{~ms}$. Oleh karena itu Brugada memasukkan 2 kategori tersebut, yaitu tidak adanya kompleks RS pada sandapan prekordial dan interval RS > 100 ms pada algoritmenya. ${ }^{1}$

Berdasarkan penemuan tersebut maka Brugada et al membuat algoritme bertingkat sebagai berikut:

Brugada et al kemudian melakukan uji diagnostik untuk algoritme baru tersebut dan mendapatkan hasil yang cukup baik. Uji diagnostik dilakukan untuk setiap langkah dari algoritme bertingkat tersebut dan mendapatkan hasil akhir sensivisitas berupa $98.7 \%$ 
dan spesifisitas berupa $96.5 \%$ untuk diagnosa VT dan sensivisitas berupa $96.5 \%$ dan spesifisitas berupa 98.7 $\%$ untuk diagnosa SVT dengan aberansi. ${ }^{1}$

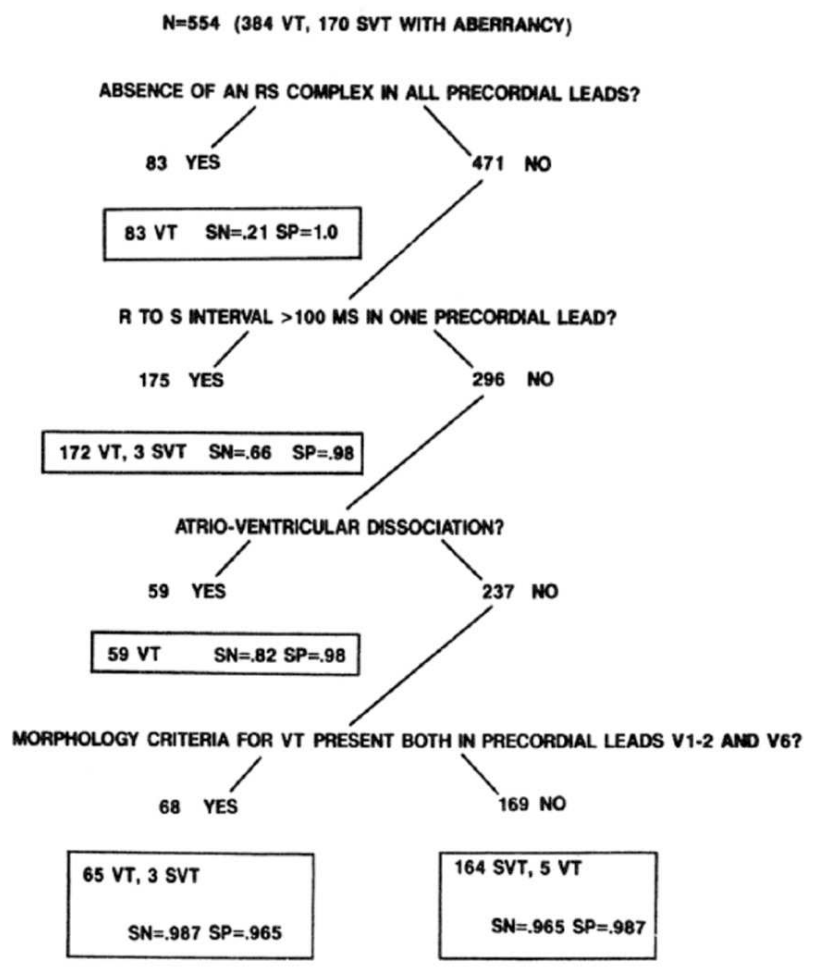

Gambar 2. Algoritme bertingkat yang dibuat oleh Brugada et al beserta hasil dari uji diagnostiknya. ${ }^{1}$

\section{Algoritme Vereckei}

Pada tahun 2007 Vereckei et al kembali meneliti kriteria-

kriteria yang dapat digunakan untuk membedakan V'T dan SVT dengan aberansi pada takikardia dengan kompleks QRS lebar. Vereckei et al tetap menggunakan kriteria disosiasi atrioventrikular karena merupakan karakteristik yang patognomonik untuk VT dengan angka spesivisitas $100 \%$. Kriteria baru yang digunakan oleh Vereckei et al adalah adanya gel R pada awal kompleks QRS di sandapan aVR, morfologi kompleks QRS yang tidak menyerupai blok berkas cabang ataupun blok fasikular, dan perbandingan antara initial velocity $\left(\mathrm{v}_{\mathrm{i}}\right)$ dan terminal velocity $\left(\mathrm{v}_{\mathrm{t}}\right) .^{5}$

Adanya gel R pada awal kompleks QRS di sadapan aVR berbeda dengan karakteristik aksis sebelumnya yang hanya melihat deviasi aksis ke kiri yang pada umumnya menghasilkan hasil vektor positif di sanda- pan aVR, namun pada kriteria ini dibutuhkan adanya gelombang R pada awal kompleks QRS. Karena sumber irama VT berasal dari ventrikel, maka arah impuls umumnya mengarah ke atas pada fase awal sehingga menimbulkan defleksi positif pada awal kompleks QRS pada sandapan aVR. ${ }^{5}$

Morfologi kompleks QRS yang yang tidak menyerupai blok berkas cabang ataupun blok fasikular dianggap sebagai pertanda dari VT karena pada SVT dengan aberansi impuls tetap akan melalui berkas his kemudian ke salah satu cabang berkas cabang sehingga akan memberikan gambaran blok berkas cabang ataupun blok fasikular. Vereckei menggunakan kriteria yang diajukan oleh Willems et al. . $^{5-6}$

Kriteria $\mathrm{v}_{\mathrm{i}} / \mathrm{v}_{\mathrm{t}}$ dipakai untuk menunjukkan arah dan kecepatan hantaran dari impuls listrik saat terjadi takikardia. $\mathrm{V}_{\mathrm{i}}$ atau initial velocity adalah voltase dalam milivolt $40 \mathrm{~ms}$ setelah awal kompleks QRS yang dianggap menggambarkan penjalaran impuls pada saat mula-mula depolarisasi ventrikel. Sedangkan $v_{t}$ atau terminal velocity adalah voltase dalam milivolt $40^{\mathrm{t}}$ ms sebelum akhir dari kompleks QRS yang dianggap menggambarkan penjalaran impuls pada saat menjelang akhir dari depolarisasi ventrikel. Pada takikardia kompleks QRS lebar yang disebabkan oleh SVT dengan aberansi impuls pertama kali timbul pada septum ventrikel melalui berkas his sehingga penjalaran impuls cenderung lebih cepat, kemudian impuls terus menjalar sampai ke otot ventrikel dimana impuls menjalar dari sel otot ke sel otot yang berjalan lebih lambat, sehingga $v_{i}>v_{t}$. Sebaliknya yang terjadi pada VT sehingga $v_{\mathrm{i}}<\mathrm{v}_{\mathrm{t}}$. Sandapan yang diambil adalah

Tabel 1. Kriteria blok berkas cabang dan blok fasikular yang diajukan oleh Willems et al dan diadopsi oleh Vereckei et al. 3,11

\begin{tabular}{|c|c|}
\hline \multicolumn{2}{|l|}{ Definition of ventricular conduction deluss } \\
\hline A. Complete B88s & B. Focccular blocts \\
\hline 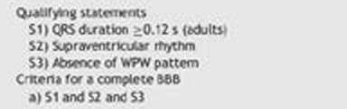 & 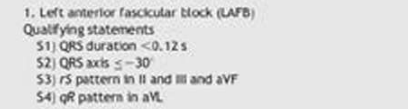 \\
\hline 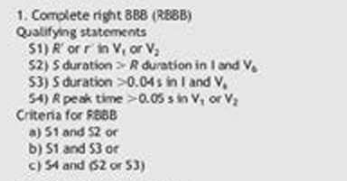 & 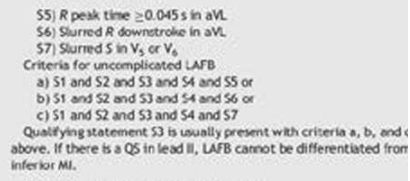 \\
\hline 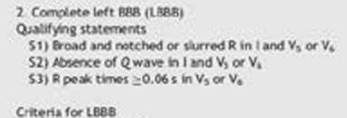 & 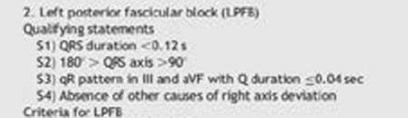 \\
\hline $\begin{array}{l}\text { Cineris for LB88 } \\
\text { s) S1 and S2 and S3 }\end{array}$ & $\begin{array}{l}\text { Criteris fac L LFB } \\
\text { a) } 51 \text { and } 52 \text { and } 53 \text { and S4 }\end{array}$ \\
\hline 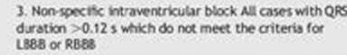 & \\
\hline
\end{tabular}



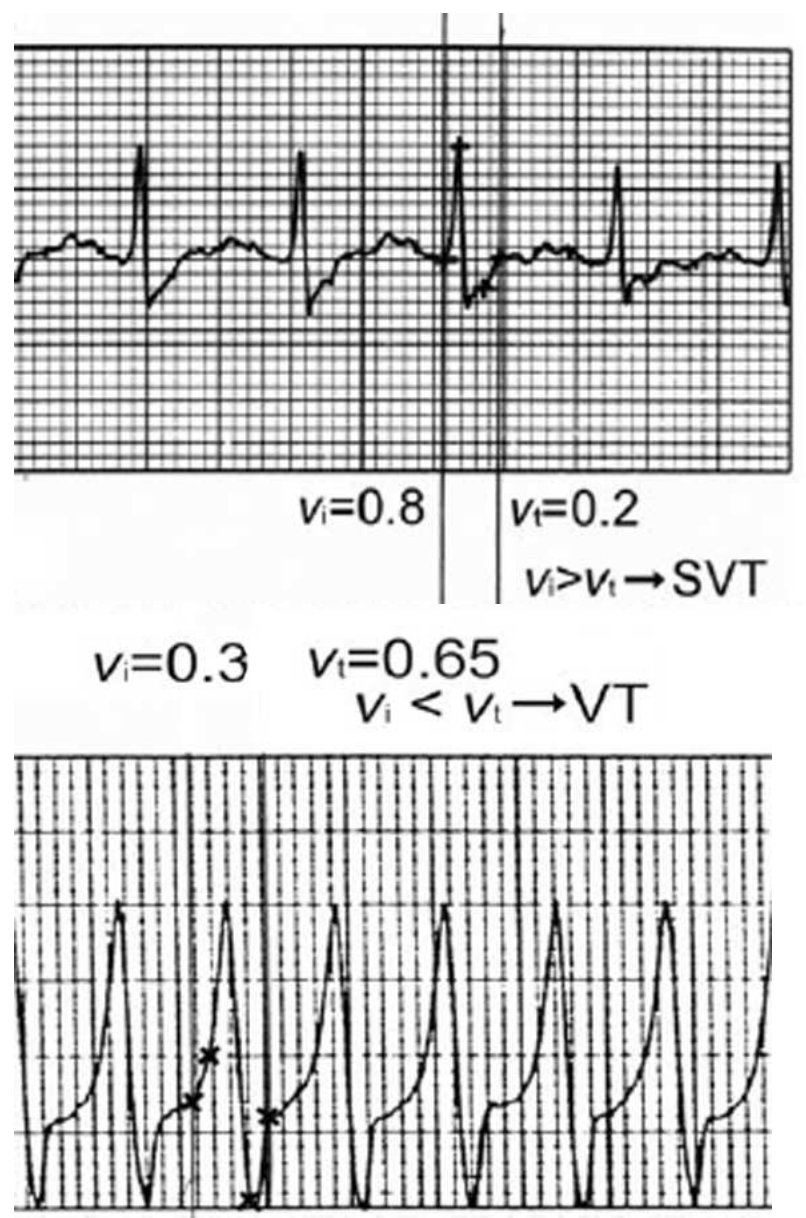

Gambar 3. Contoh penggunaan kriteria $v_{i} / v_{t}$ pada EKG yang menunjukkan diagnosis SVT (atas) dan VT (bawah)

sandapan yang memiliki $\mathrm{v}_{\mathrm{i}}$ paling cepat. ${ }^{5}$

Vereckei kemudian menguji akurasi dari algoritme baru tersebut dan membandingkannya dengan algoritme Brugada dan mendapatkan algoritme baru memiliki spesifisitas sebesar $72,4 \%$ dan sensitivitas sebesar 95.7\%, sementara algoritme Brugada memiliki spesifisitas sebesar $73.3 \%$ dan sensitivitas sebesar $88.2 \% .^{5}$

\section{Algoritme aVR}

Pada tahun 2008 Vereckei kembali membuat algoritme baru dengan prinsip yang baru, yaitu algoritme yang dibuat hanya berdasarkan prinsip perbedaan dari arah dan kecepatan impul pada awal dan akhir dari aktivasi ventrikel saat takikardia dengan QRS lebar.,
453 WCTs (348 VTs, 105 SVTs)

Step 1.

A-V dissociation present?

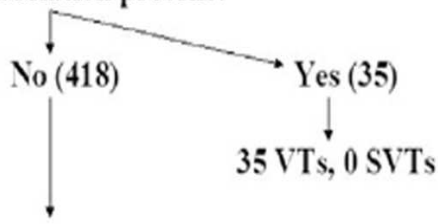

Step 2. Initial $\mathrm{R}$ wave in aVR present?

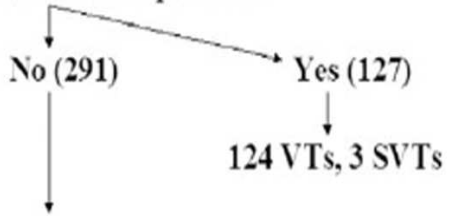

Step 3. QRS morphology unlike BBB or FB?

Step 4.
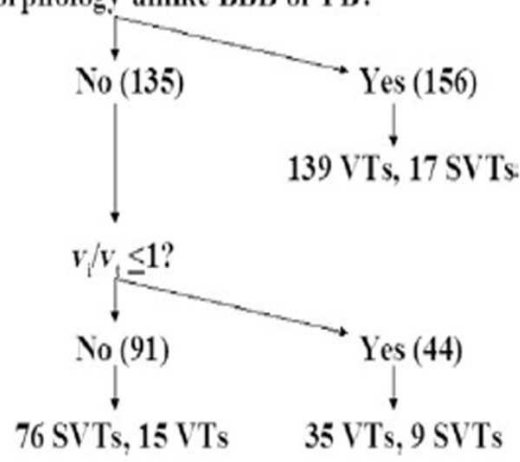

Gambar 4. Algoritme dari Vereckei dan uji diagnostiknya. ${ }^{5}$

Algoritme aVR ini dibuat berdasarkan 3 konsep baru yaitu: 1. Penggunaan hanya sandapan aVR untuk membedakan VT dan SVT dengan aberansi, 2. Algoritme ini dapat membedakan VT ke dalam 2 grup yaitu: a.VT yang timbul dari daerah apikal atau inferior ventrikel, dan b. VT yang timbul dari daerah ventrikel lainya, dan 3. Algoritme pertama yang tidak menggunakan disosiasi atrioventrikular yang selalu digunakan oleh sebelumnya. ${ }^{7}$

Algoritme ini dibuat untuk melengkapi kelemahan dari algoritme sebelumnya dimana gelombang $\mathrm{R}$ awal kompleks QRS di sandapan aVR hanya timbul pada VT dengan fokus di daerah apikal atau inferior saja. Vereckei meneliti gambaran EKG apabila irama VT yang timbul berasal dari tempat lain seperti di daerah ventrikel kanan ataupun daerah basal. Sehingga dengan algoritme ini selain dapat membedakan irama VT dan SVT dengan aberansi pada takikardia dengan 


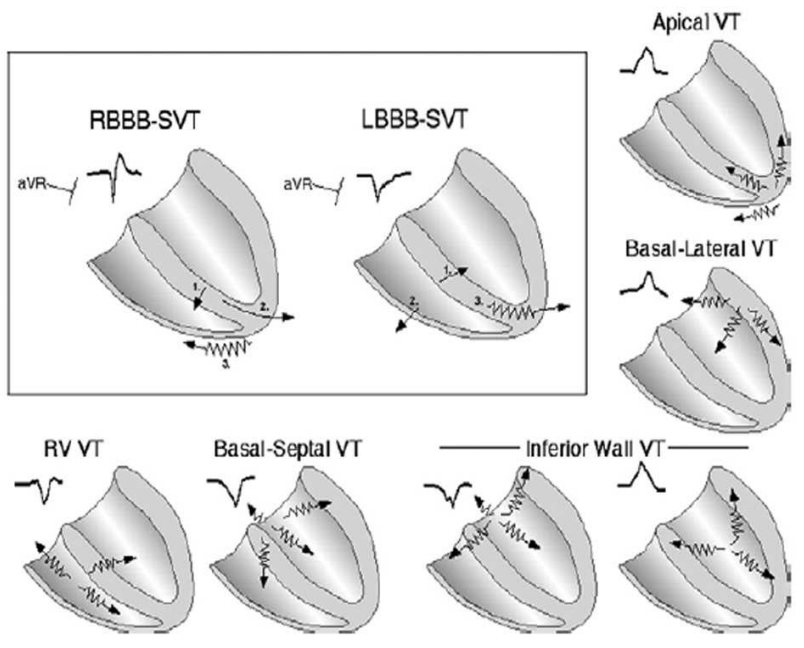

Gambar 5. pengaruh asal dan penjalaran impuls terhadap gambaran EKG di sandapan aVR. Garis lurus : impuls yang berjalan melalui conduction pathway. Garis zig zag : impuls yang berjalan secara aberan melalui sel-sel otot jantung. ${ }^{7}$

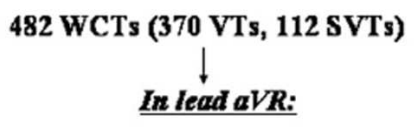

Step 1. Presence of an initial $R$ wave?

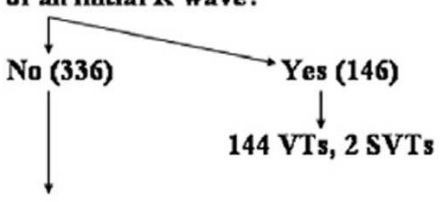

Step 2. Presence of an initial $q$ or $r$ wave $>40 \mathrm{~ms}$ ?

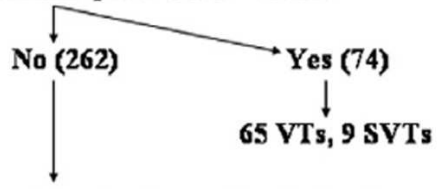

Step 3. Presence of a notch on the descending limb of a negative onset and predominantly negative QRS?

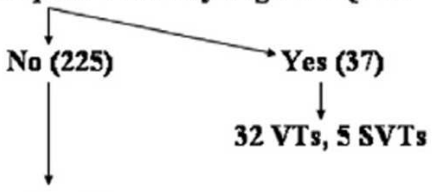

Step 4.

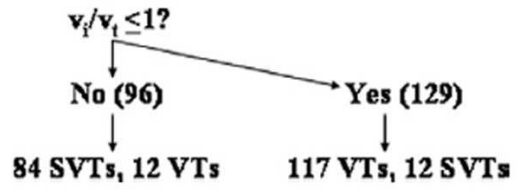

Gambar 6. Algoritme baru dari Vereckei yang hanya menggunakan sandapan aVR beserta uji diagnostiknya. ${ }^{\text {? }}$ kompleks QRS lebar, kita juga dapat memprediksi asal dari impuls VT tersebut.

Untuk mengatasi kelemahan tersebut maka Vereckei menambahkan 2 langkah baru yaitu adanya

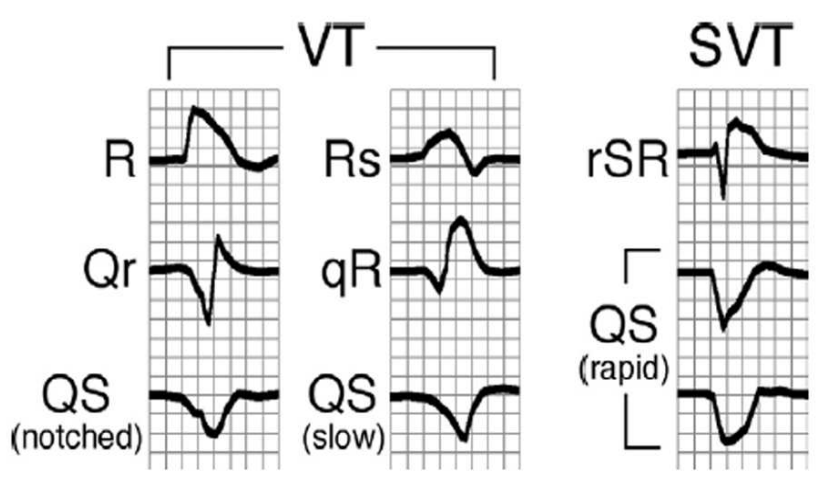

Gambar 7. Contoh penerapan langkah ke 2 dan ke 3 dari algoritme aVR, yaitu gelombang $r$ atau q pada awal QRS di sandapan aVR dengan lebar $>40$ ms dan adanya takik pada bagian defleksi menurun dari gelombang q pada kompleks QRS di sandapan aVR. ${ }^{7}$

gelombang q atau $\mathrm{r}>40 \mathrm{~ms}$ dan adanya takik pada gelombang negatif pada awal kompleks QRS di sandapan aVR.?

Vereckei et al kemudian melakukan uji diagnostik untuk membandingkan ke 3 algoritme yang sudah ada, yaitu algoritme Brugada, Vereckei, dan aVR dan mendapatkan spesifisitas ketiga algoritme tersebut secara berurutan adalah: $73.2 \%, 74.1 \%$, dan $75 \%$, sementara sensitivitasnya adalah: 89\%, 95.7\%, 96.5\%. Selain itu, Vereckei et al menyebutkan waktu yang dibutuhkan untuk membuat diagnosis VT atau SVT dengan aberansi jauh lebih singkat dengan menggunakan algoritme aVR bila dibandingkan dengan algoritme Vereckei dan Brugada. ${ }^{7}$

\section{Algoritme Ultrasimple Brugada}

Algoritme Ultrasimple Brugada atau R-Wave Peak Time adalah karakteristik EKG baru yang diajukan oleh Brugada et al pada tahun 2010. Algoritme ini unik karena hanya terdiri dari satu langkah saja sehingga membuatnya cukup mudah digunakan. Algoritme ini dibuat berdasarkan penelitian yang mengatakan bahwa impuls yang menyebar pada otot jantung secara transversal akan berjalan lebih lambat bila dibandingkan 
dengan impuls yang berjalan secara longitudinal. ${ }^{8}$

Valderrábano mengadakan penelitian dan menemukan impuls yang berjalan secara transversal akan berjalan lebih lambat bila dibandingkan dengan impuls yang berjalan secara longitudinal. Sifat konduksi yang anisotropik ini disebabkan oleh karena gap junction pada otot jantung tidak tersebar secara merata dan

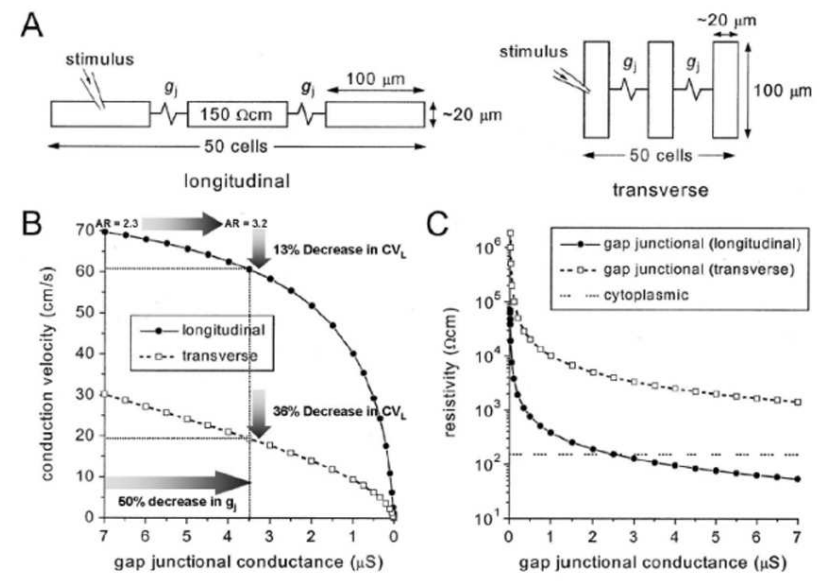

Gambar 8. Hasil penelitian dari Valderrábano: A. Skema yang memperlihatkan stimulus yang menghasilkan impuls yang berjalan longitudinal (kiri) dan transversal (kanan). B. (Kiri) grafik yang menunjukkan perbedaan kecepatan konduksi pada impuls yang berjalan longitudinal dan transversal, dapat pula terlihat menurunnya gap junctional conductance akan menyebabkan kecepatan konduksi turun lebih jauh pada impuls yang berjalan transversal. (kanan) grafik yang menunjukkan tahanan pada impuls yang berjalan transversal lebih tinggi bila dibanding dengan longitudinal. ${ }^{9}$

lebih banyak terdapat pada ujung-ujung otot jantung, sehingga impuls akan lebih mudah dihantarkan bila berjalan secara longitudinal melalui otot jantung. ${ }^{9}$

Berdasarkan teori tersebut Brugada et al kembali membuat kriteria EKG yang jauh lebih sederhana dan hanya terdiri dari satu langkan untuk membedakan VT dan SVT dengan aberansi pada takikardia dengan kompleks QRS lebar. Kriteria itu sering disebut $R$ Wave Peak Time pada sandapan II yaitu dengan mengukur jarak dari awal kompleks QRS di sandapan II sampai pada puncak dari gelombang defleksi pertama pada kompleks QRS tersebut terlepas apakah defleksi tersebut positif atau negatif. ${ }^{8}$

Dengan menggunakan perhitungan area under curve didapatkan nilai batas yang dipakai adalah 50 ms. Setelah dilakukan pengujian, ternyata kriteria ini

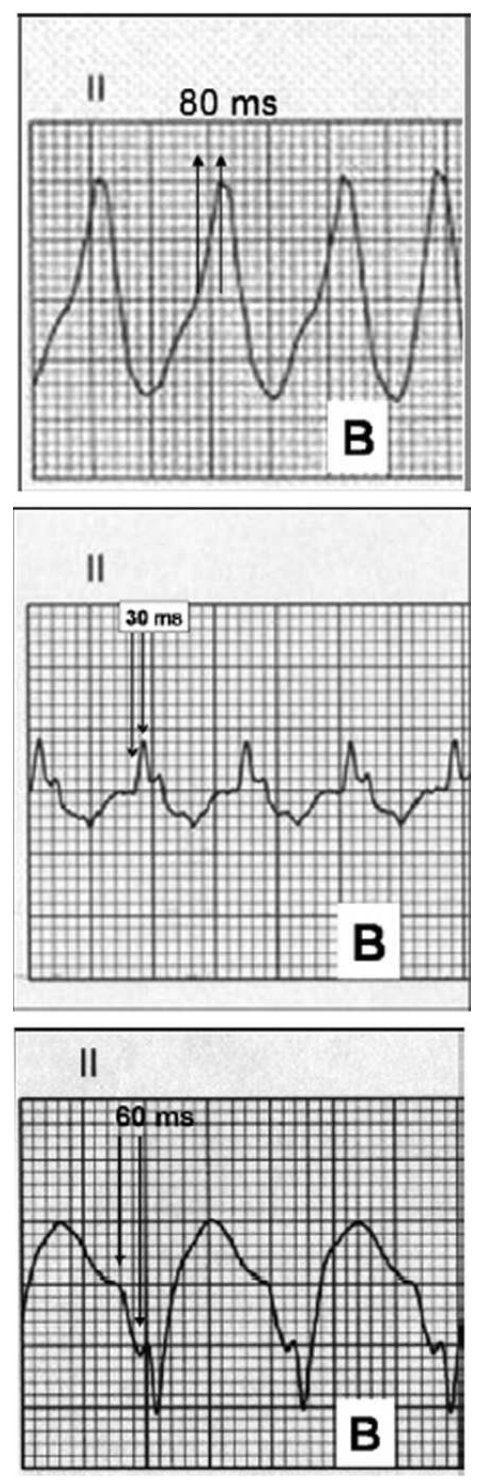

Gambar 9. contoh penerapan algortime R-Wave Peak Time pada EKG. (atas) VT, (tengah) SVT dengan aberansi, (bawah) EKG dengan defleksi pertama kompleks QRS ke bawah $^{10}$

Tabel 2. Tes akurasi pada kriteria R-Wave Peak Time > $50 \mathrm{~ms}$ pada sandapan II8

\begin{tabular}{ll}
\hline Test & Value \\
\hline Sensitivity & $93.2(67.3-93.2)$ \\
Specificity & $99.3(74.1-99.8)$ \\
Positive predictive value & $98.2(89-99.8)$ \\
Negative predictive value & $93.3(87.9-96.4)$ \\
Area under the curve & $0.98(0.95-0.99)$ \\
Positive likelihood ratio & 51.3 \\
Negative likelihood ratio & 0.06 \\
Interobserver agreement & $\kappa=0.86$ \\
\hline
\end{tabular}


Jurnal Kardiologi Indonesia

Tabel 3. Perbandingan akurasi, sensitivitas, spesivisitas, positif dan negatif likelihood ratiodari kelima algoritme yang di teliti Jastrzebski et al. ${ }^{10}$

\begin{tabular}{|c|c|c|c|c|c|c|}
\hline & Brugada & Griffith & Bayesian & Lead aVR & Lead II RWPT & $P$ \\
\hline Accuracy $(\%)$ & $\begin{array}{l}77.5 \\
(71.8-82.5)\end{array}$ & $\begin{array}{l}73.1 \\
(67.2-78.5)\end{array}$ & $\begin{array}{l}74.7 \\
(68.9-79.9)\end{array}$ & $\begin{array}{l}71.9 \\
(66.0-77.4)\end{array}$ & $\begin{array}{l}68.8 \\
(62.7-7.44)\end{array}$ & $0.04^{\mathrm{a}}$ \\
\hline Specificity (\%) & $\begin{array}{l}59.2 \\
(48.8-69.0)\end{array}$ & $\begin{array}{l}39.8 \\
(30.0-50.2)\end{array}$ & $\begin{array}{l}52.0 \\
(41.7-62.2)\end{array}$ & $\begin{array}{l}48.0 \\
(37.8-58.3)\end{array}$ & $\begin{array}{l}82.7 \\
(73.7-89.6)\end{array}$ & $<0.001^{\mathrm{b}, \mathrm{c}}$ \\
\hline Sensitivity (\%) & $\begin{array}{l}89.0 \\
(83.0-93.5)\end{array}$ & $\begin{array}{l}94.2 \\
(89.3-97.3)\end{array}$ & $\begin{array}{l}89.0 \\
(83.0-93.5)\end{array}$ & $\begin{array}{l}87.1 \\
(80.8-91.9)\end{array}$ & $\begin{array}{l}0.60 \\
(0.52-0.68)\end{array}$ & $<0.001^{b, d}$ \\
\hline $\operatorname{LR}(+)$ & $\begin{array}{l}2.18 \\
(1.71-2.78)\end{array}$ & $\begin{array}{l}1.56 \\
(1.33-1.85)\end{array}$ & $\begin{array}{l}1.86 \\
(1.50-2.30)\end{array}$ & $\begin{array}{l}1.67 \\
(1.37-2.04)\end{array}$ & $\begin{array}{l}3.46 \\
(2.20-5.43)\end{array}$ & - \\
\hline $\operatorname{LR}(-)$ & $\begin{array}{l}0.18 \\
(0.11-0.30)\end{array}$ & $\begin{array}{l}0.15 \\
(0.07-0.29)\end{array}$ & $\begin{array}{l}0.21 \\
(0.13-0.34)\end{array}$ & $\begin{array}{l}0.27 \\
(0.17-0.42)\end{array}$ & $\begin{array}{l}0.48 \\
(0.39-0.60)\end{array}$ & - \\
\hline $\begin{array}{l}\text { Numbers in paren } \\
\text { "Brugada vs. lead I } \\
\text { bead II RWPT vs. } \\
{ }^{c} P=0.01 \text { for Griff } \\
{ }^{d} P=0.05 \text { for Griff }\end{array}$ & $\begin{array}{l}\text { the } 95 \% \text { confi } \\
\text { algorithm. } \\
\text { lada or vs. Bay }\end{array}$ & & & & & \\
\hline
\end{tabular}

memiliki angka baik spesivisitas maupun sensivisitas yang fantastis. Karena algoritme ini cukup sederhana dan mudah karena hanya terdiri dari satu langkah saja, maka algoritme ini dapat digunakan secara luas dan akan memudahkan dalam mendiagnosis VT atau SVT dengan aberansi pada takikardia dengan kompleks QRS lebar. Namun pada penelitian ini Brugada et al tidak melakukan perbandingan akurasi dengan algoritme lainnya yang sudah ada. ${ }^{8}$

Dari uraian diatas dapat dilihat ada banyak algoritme yang dapat digunakan untuk membedakan VT dan SVT aberansi pada takikardia pada kompleks QRS lebar. Namun belum ada konsensus mengenai algoritme mana yang harus dipakai, dan belum ada kejelasan mengenai algoritme mana yang memiliki akurasi paling baik. Beberapa peneliti sudah mencoba untuk membandingkan algoritme-algoritme yang ada selain dari peneliti yang menemukan algoritme tersebut. Pada tahun 2012 Jastrzebski et al melakukan penelitian untuk membandingkan 5 algoritme untuk membedakan VT dan SVT dengan aberansi, yaitu Brugada, aVR, $R$-Wave Peak Time, Griffith, dan Bayesian (Tabel 3). Jastrzebski et al mendapatkan semua algoritme yang baru tidak berbeda bermakna dalam hal akurasi (persentasi keberhasilan mendiagnosis VT) secara umumnya, namun ada perbedaan yang sangat bermakna dalam sensivitas dan spesivitas dalam mendiagnosis $\mathrm{VT} .{ }^{10}$

Dari hasil diatas terllihat akurasi dari algoritme Brugada, Griffith, Bayesian dan aVR algoritme tidak berbeda bermakna, namun $R$-Wave Peak Time memi- liki spesifisitas yang cukup tinggi secara bermakna, sehingga dengan algoritmenya yang hanya terdiri dari satu langkah algoritme ini dapat dengan cukup mudah digunakan untuk mendiagnosis VT. Meskipun demikian, karena sensivitasnya yang sangat rendah, maka algortime ini tidak dapat digunakan untuk menyingkirkan VT. ${ }^{10}$

\section{Penutup}

Dari uraian diatas terlihat cukup jelas masih rintangan yang harus dihadapi untuk dapat mendiagnosis takikardia dengan kompleks QRS lebar dengan tepat. Banyak usaha yang sudah dilakukan oleh para peneliti dengan membuat berbagai algoritme dan karakteristik EKG namun belum dapat memberikan metode dengan akurasi yang cukup tinggi sehingga masih perlu dilakukan penelitian untuk mengkaji ulang dari karakteristik EKG dan algoritme yang ada, bahkan mungkin masih dapat ditemukan karakteristik EKG yang baru atau bahkan algoritme yang baru yang dapat membantu diagnosis dari takikardia dengan kompleks QRS lebar.

\section{Daftar Pustaka}

1. Brugada P., Brugada J., Mont L., Smeets J., Andries E. W. A new approach to the differential diagnosis of a regular tachycardia 
with a wide QRS complex. Circulation. 1991;83(5):1649-59.

2. Issa Z., Miller J. M., Zipes D. P. Approach to Wide QRS Complex Tachycardias. In: Issa Z., Miller J. M., Zipes D. P., editors. Clinical Arrhythmology and Electrophysiology: a Companion to Braunwald's Heart Disease. 1 ed. Philadelphia: Elsevier; 2009. p. 393-403.

3. R. Subramanian, J. Brady W. Wide Complex Tachycardia: Diagnosis And Management In The Emergency Department. EBMedicine. 2008;10(6):1-23.

4. Wellens H. J., Bar F. W., Lie K. I. The value of the electrocardiogram in the differential diagnosis of a tachycardia with a widened QRS complex. The American journal of medicine. 1978;64(1):27-33.

5. Vereckei A., Duray G., Szenasi G., Altemose G. T., Miller J. M. Application of a new algorithm in the differential diagnosis of wide QRS complex tachycardia. European heart journal. 2007;28(5):589-600.

6. Willems J. L., Robles de Medina E. O., Bernard R., Coumel P., Fisch C., Krikler D., et al. Criteria for intraventricular conduction disturbances and pre-excitation. World Health Organizational/International Society and Federation for Cardiology Task
Force Ad Hoc. Journal of the American College of Cardiology. 1985;5(6):1261-75.

7. Vereckei A., Duray G., Szenasi G., Altemose G. T., Miller J. M. New algorithm using only lead aVR for differential diagnosis of wide QRS complex tachycardia. Heart rhythm : the official journal of the Heart Rhythm Society. 2008;5(1):89-98.

8. Pava L. F., Perafan P., Badiel M., Arango J. J., Mont L., Morillo C. A., et al. R-wave peak time at DII: a new criterion for differentiating between wide complex QRS tachycardias. Heart rhythm : the official journal of the Heart Rhythm Society. 2010;7(7):922-6.

9. Valderrabano M. Influence of anisotropic conduction properties in the propagation of the cardiac action potential. Progress in biophysics and molecular biology. 2007;94(1-2):144-68.

10. Jastrzebski M., Kukla P., Czarnecka D., Kawecka-Jaszcz K. Comparison of five electrocardiographic methods for differentiation of wide QRS-complex tachycardias. Europace : European pacing, arrhythmias, and cardiac electrophysiology : journal of the working groups on cardiac pacing, arrhythmias, and cardiac cellular electrophysiology of the European Society of Cardiology. 2012;14(8):1165-71. 